\title{
BMJ Open Does weight-related stigmatisation and discrimination depend on educational attainment and level of income? A systematic review
}

\author{
Marie Bernard (D) , ${ }^{1,2}$ Thomas Fankhänel, ${ }^{2}$ Steffi G Riedel-Heller, ${ }^{3}$ \\ Claudia Luck-Sikorski ${ }^{1,2}$
}

To cite: Bernard M, Fankhänel T, Riedel-Heller SG, et al. Does weight-related stigmatisation and discrimination depend on educational attainment and level of income? A systematic review. BMJ Open 2019;9:e027673. doi:10.1136/ bmjopen-2018-027673

- Prepublication history and additional material for this paper are available online. To view these files, please visit the journal online (http://dx.doi org/10.1136/bmjopen-2018027673).

Received 12 November 2018 Revised 16 0ctober 2019 Accepted 18 0ctober 2019

Check for updates

(C) Author(s) (or their employer(s)) 2019. Re-use permitted under CC BY-NC. No commercial re-use. See rights and permissions. Published by BMJ.

${ }^{1}$ Integrated Research and Treatment Center AdiposityDiseases (IFB), University of Leipzig, Leipzig, Germany

${ }^{2}$ SRH University of Applied Health Sciences, Gera, Germany ${ }^{3}$ Institute of Social Medicine, Occupational Health and Public Health (ISAP), University of Leipzig, Leipzig, Germany

Correspondence to Marie Bernard; marie.bernard@medizin.unileipzig.de

\section{ABSTRACT}

Objectives Obesity is considered a global health issue, because of its health-related consequences and also because of its impact on social status as a result of stigma. This study aims to review the quantitative state of research regarding socioeconomic characteristics' influence on weight-related stigmatisation and discrimination. Based on Bourdieu's Theory of Class and his concept of 'habitus', it is assumed that people with a higher level of education and income show stronger negative attitudes towards people with obesity.

Method A narrative systematic literature review was conducted in 2017 using PubMed, PsychINF0, Web of Science and the Cochrane Library. Seventeen studies that measured weight bias and either educational attainment or level of income were included in the analysis.

Results The results of the studies included were inconsistent: six of these studies were found to support the hypothesis, whereas two of the studies contradicted it. The remaining seven studies did not show any significant correlation between weight bias and either education or income.

Conclusion In light of the inconsistent and heterogeneous results of the studies that report a significant association between weight bias and socioeconomic variables, the findings must be discussed concerning their cultural context, that is, cultural and governmental differences. Furthermore, educational attainment seems to be more likely to predict weight bias than income. The review revealed a lack of research when it came to examining the impact of socioeconomic capital on weight bias.

\section{INTRODUCTION}

According to the WHO, the worldwide prevalence of obesity, defined by a body mass index (BMI) of over $30 \mathrm{~kg} / \mathrm{m}^{2}$, nearly tripled

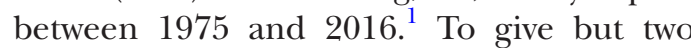
examples, current data reveal an obesity rate of over $21 \%$ in Germany and $37.7 \%$ in the USA. $^{2}$ With its escalating rate, obesity can be classified as a global health issue, primarily because it is associated with numerous comorbid diseases, such as diabetes mellitus,
Strength and limitations of this study

- A systematic review following the PRISMA guidelines was conducted to investigate the relationship between weight bias and the socioeconomic status of studies published in English or German.

- Study selection was performed by two independent reviewers to minimise subjectivity and random errors.

- This study is limited since no meta-analysis could be performed due to divergent study designs, instruments used or different ways items were operationalised for statistical analysis.

cardiovascular diseases and certain forms of cancer. $^{4}$

Health-related consequences are connected to obesity and psychological implications that affect those concerned on a social level. ${ }^{5}$ In particular, obesity is classified as a stigmatised condition. Therefore, being obese is a characteristic that sets those affected apart from people with normal weight. Since obesity is mislabelled as a self-inflicted situation, numerous negative stereotypes, such as laziness, lack of willpower, unhealthy lifestyle and being unintelligent are associated with the condition. ${ }^{67}$ Stigmatisation leads to discriminating behaviour towards people with obesity in the form of mistreatment in several areas of life, such as labour market, healthcare and educational system. ${ }^{67}$

The systematic review of Spahlholz ${ }^{8}$ revealed increased perceived discrimination towards people with obesity in comparison to people with normal weight, especially towards people with more extreme obesity (BMI $>35 \mathrm{~kg}$ / $\mathrm{m}^{2}$ ) as well as towards women. Moreover, the prevalence of weight-related discrimination accelerated over time. In the USA, the prevalence of weight-related discrimination was nine times higher (66\%) in 2005 than in 1995 
$(7.3 \%)^{78}$ and is thus similar to the rate of racial discrimination, particularly against women. ${ }^{9}$ Understanding the origin of stigma, which can be seen as the catalyst for structural discrimination, is necessary to prevent discriminating behaviour. Although weight-related stigmatisation and discrimination are closely linked, they need to be considered as two divergent concepts. However, in the following, we will refer to weight-related stigmatisation and discrimination as 'weight bias', but will differentiate between both concepts whenever needed.

Some people are more prone to display weight bias than other: There is some evidence that older age is associated with stigmatising attitudes ${ }^{10-12}$ and stronger evidence that men show stronger weight bias than women. ${ }^{13-16}$ When looking at the body and beauty perception of people, the cultural framework also needs to be considered as a determinant of stigma. According to Bourdieu, the predominant cultural context determines which values and characteristics can be seen either as desirable or traits to be stigmatised. ${ }^{17}$ Depending on regional characteristics, weight is perceived as a sign of class distinction: In undeveloped countries, overweight was associated positively with well-being and wealth, while in developed countries, a negative view of being overweight was widespread. Thus, in developed countries, thinness has been viewed as a sign of beauty, success and an overall high (socioeconomic) status. ${ }^{18}$ Although in the last few decades the perception of obesity or rather slim-body ideals developing countries might have changed, ${ }^{19}{ }^{20}$ results indicate that educational attainment and level of income seem to be relevant regarding weight bias.

Although socioeconomic variables and obesity correlate closely, the impact of educational attainment and level of income on weight bias remain ambiguous. Several studies have shown the negative impact of being overweight on the labour market, especially for women ${ }^{21} 22$ as well as in the education system. ${ }^{23}$ In addition, a lower level of education and income is associated with obesogenic behaviour such as a poor diet and a lack of exercise caused by factors such as stress. ${ }^{24}$ Moreover, Bourdieu ${ }^{25}$ sees the most decisive determinant of a healthy lifestyle in socioeconomic class. While people that belong to the working class preferred tasty and nutritious food, people from the upper-middle class preferred food that can be described as light, healthy and low in calories, according to his study. Subsequently, people with a higher level of education and income might choose a healthier lifestyle to distance themselves from people with obesity. ${ }^{26}$

As a superior framework to generate missing hypotheses, Bourdieu's Theory of Class can be applied. ${ }^{25}$ Following his concept of 'habitus', a person's general attitude, lifestyle and even body shape can be seen as a metaphor for social status. ${ }^{18}$ Furthermore, Bourdieu considers stigma as a form of symbolic power and a tool to serve the interests of the powerful. ${ }^{27}$ Phelan and colleagues ${ }^{28}$ continue with his line of thought and presented three motives of stigma, namely keeping people in, away or down. Particularly, keeping people down applies to the review's theoretical framework.
Link and Phelan ${ }^{17}$ discuss stigma as an instrument of a dominant group to keep another group down to attain or maintain high social status, wealth and power. However, a person's educational attainment and level of income are mainly invisible characteristics; thus, there are other attributes that more readily show social status. Assuming that obesity is perceived as a metaphor for lower social status, groups with higher social status might be aware of this link and keep people with obesity down to empower themselves. In this review, it is therefore assumed that people with a higher level of education and income display negative attitudes towards people with obesity in comparison to people with lower educational attainment and income. The impact of educational attainment and level of income on weight bias will be examined and compared.

Based on a sociological perspective, this systematic literature review attempts to outline the current state of research and reveal the relationship between weight bias and the level of education and income. Tyler and Slater ${ }^{29}$ criticised inter alia 'that one of the major limitations of existing understandings of stigma is the ways in which they have 'bracketed off' key questions, such as where stigmatizing attitudes come from, how and by whom is stigma crafted, mediated, produced and why [...].'. The general aim of this review is thus to identify social and economic groups that stigmatise and discriminate against those who are obese. In the future, this information could help researchers to develop and implement interventions in a more targeted manner.

\section{METHODS}

\section{Search strategy}

A systematic review of published studies reporting weightrelated attitudes held by differing socioeconomic status groups was conducted by using the relevant scientific electronic databases: PubMed, PsychINFO, Web of Science and the Cochrane Library. The review followed the Prisma Guidelines. ${ }^{30}$

The systematic review of literature was performed independently by two reviewers using the following keywords: stigma*, discrimination, "weight bias", or prejudice; education*, income, salary, wage, status, socio-economic, socioeconomic*, SES, sociodemographic, or sociodemographics; and obes*, overweight, or fat. Giving a very high number of results, the literature search was limited to the publications' titles and abstracts. Only published studies written in English or German were included. There was no restriction regarding the year of publication. The stages of the systematic literature search are provided in figure 1 . The literature review was conducted for all studies that have been published until June 2019.

\section{Data extraction}

The systematic search of the literature revealed 2331 studies, whereby 1708 studies remained after removing duplicates. Furthermore, 1510 studies were excluded because screening their titles and abstracts 


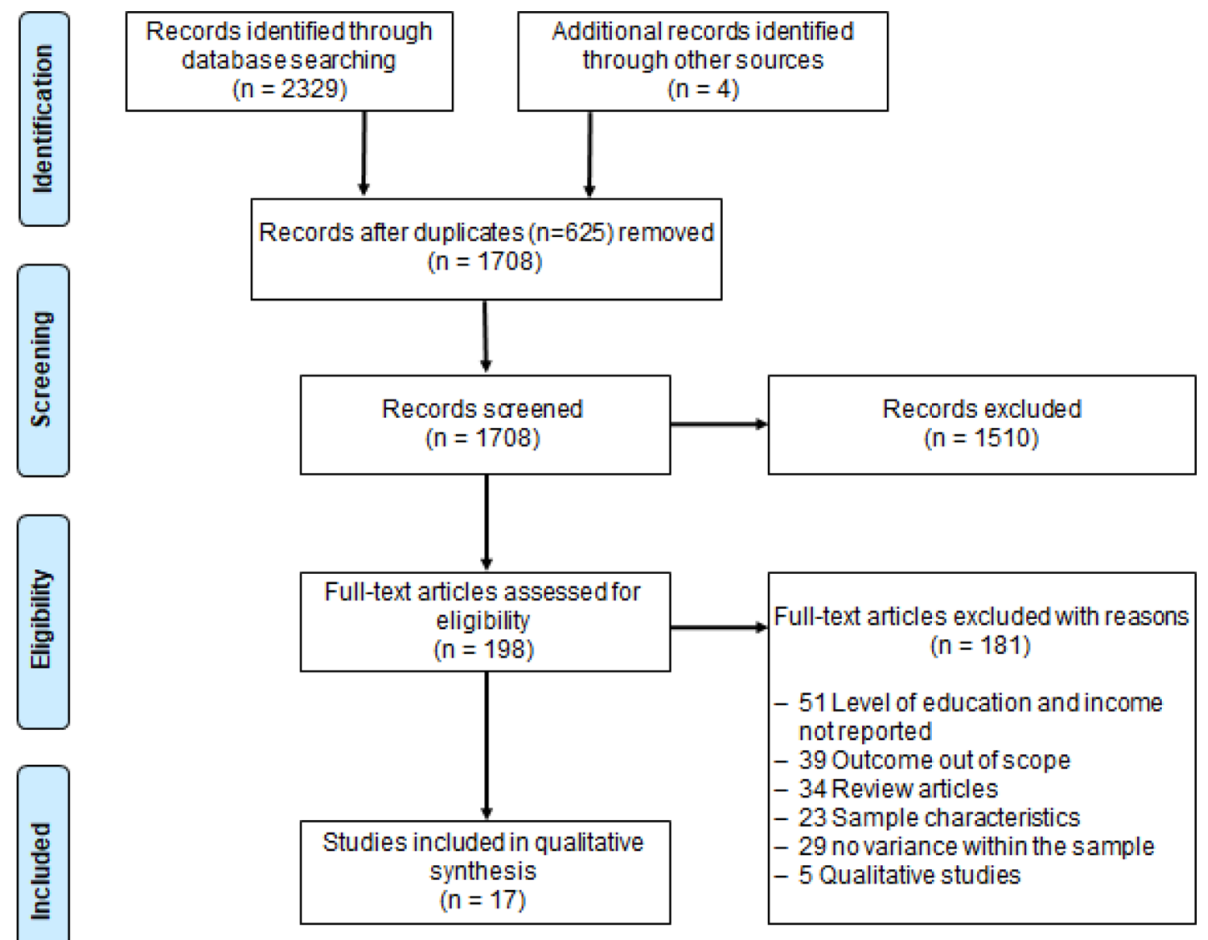

Figure 1 Phases of the systematic review.

for eligibility showed no association with the research question. Disagreement and uncertainty between the two reviewers over the eligibility were resolved by reinspecting the papers in detail and discussing disparate perspectives. For the remaining 198 studies, full articles were screened in detail to assess their eligibility. For data extraction we used an adjusted PICO scheme: ${ }^{31}$ Studies that collected data of an adult sample (P) which assessed stigmatising and discriminating attitudes (I) depending on socioeconomic variables $(\mathrm{C})$ to investigate if weight bias is associated with socioeconomic status $(\mathrm{O})$. The detailed inclusion and exclusion criteria are presented in the following.

\section{Inclusion criteria}

Studies that report associations between weight bias and either educational attainment or level of income were included. Weight bias was operationalised to reflect stigmatising and discriminating attitudes. Therefore, studies that measured stigmatising attitudes by applying explicit and implicit instruments will be included, but also studies that assessed causal beliefs about obesity, which can be considered as proxy variable as previously done before. ${ }^{32}$ Studies that assessed discriminating attitudes, for example, by measuring the support for weightrelated antidiscrimination policies and law or considering obesity as a financial burden are considered for inclusion. According to Woolford et $a l^{33}$ who found less support to cover obesity-related costs by public health insurances, the public's opinion can be seen as a potential guideline for insurance funds. ${ }^{33}$ In other words, based on the public's view, discrimination might occur in the field of health insurance policies. This assumption might be of particular importance when considering the increased obesity-related healthcare cost. ${ }^{34}$

\section{Exclusion criteria}

The following exclusion criteria were used to eliminate studies that were not applicable: (1) studies with a sample of healthcare professionals, dietitians, psychologists and physical educators; (2) studies that investigated stigmatising attitudes of children and/or adolescents; (3) studies that investigated stigma towards childhood obesity; (4) studies with an overweight and/or obese sample that investigated perceived stigmatisation; (5) studies with a homogenous sample in regard to educational attainment (eg, students) or level of income; (6) studies that investigated weight bias towards extended stigma groups (eg, obese and binge eating) and (7) reviews or qualitative studies. The flowchart (figure 1) displays how many studies were excluded in accordance with the exclusion criteria. In summary, 50 studies were excluded because they did not report the participants' educational attainment or income. In addition, 29 studies did assess data of a sample with no variance concerning socioeconomic characteristics and 23 studies were excluded because of the samples' characteristics (overweight/obese or children/ adolescents sample). Five studies were excluded because they followed a qualitative approach and 34 studies were excluded because they could be categorised as reviews. Thirty-nine studies were found that did not meet the criteria for the aimed outcome of weight bias. Two studies were neither published in English nor German. 
Moreover, one paper had to be excluded because of its lack of academic background. After excluding the studies that did not meet our criteria, 17 studies were identified as relevant for in-depth investigation (figure 1). Therefore, sampling characteristics, study design, assessment of weight bias and measurement of educational attainment and income were systematically examined.

\section{Risk of bias}

We assessed the risk of bias of all studies included using the Appraisal tool for Cross-Sectional Studies (AXIS) developed by Downes and colleagues. ${ }^{35}$ The studies were therefore examined regarding potential causes that might induce a specific risk of bias.

\section{Patient and public involvement}

Within this study, no patient data were collected. We conducted a systematic review and analysed data that had already been collected. Thus, patients were not involved in this study.

\section{RESULTS}

The 17 studies included were tabulated according to the following characteristics: the origin of the sample, sample size (N), sample characteristics, study design, instruments to assess weight bias, educational attainment or income and a summary of results. Studies reviewed in detail are tabulated by either educational attainment (table 1 ) or by the level of income (table 2).

\section{Study characteristics}

All relevant study characteristics are summarised in tables 1 and 2, respectively. Seven out of 17 studies are based entirely on an American sample. ${ }^{36-42}$ Two other studies are based on an American and an Icelandic sample. ${ }^{43}$ These two studies also provided data based on a Canadian sample of healthcare professionals and American, Australian and Icelandic student samples that did not meet the inclusion criteria and therefore all four samples had to be excluded. Three studies were based on a German sample ${ }^{104546}$ and five studies based on one sample, from Paraguay, ${ }^{47}$ Mexico, ${ }^{48}$ Sweden, ${ }^{49}$ Denmark $^{50}$ and Great Britain, ${ }^{51}$ respectively. The study by Brewis and Wutich, ${ }^{47}$ based on a Paraguayan sample also provided data of a comparison group of US-undergraduate students that were not considered in the analysis because of the homogenous study sample in terms of educational attainment. The 17 studies included showed a wide variety of sample sizes ranging from $198^{51}$ to 3502 participants. ${ }^{37}$

Since the aim of the study was to outline the impact that socioeconomic status in the form of educational attainment and level of income have on weight bias, attention was paid to a variation in these variables within the samples. The studies included therefore focused either on a population-based sample 103839454649 or an convenience sample. ${ }^{374041434450}$ Although Jiminez-Cruz and colleagues ${ }^{48}$ investigated stigmatising attitudes of an entirely low-income sample, they divided the socioeconomic factors (level of education and income) into five and four categories, respectively; thus, variation within the sample could be ensured. Moreover, an investigation of weight bias in different gradations of lower status groups could provide further insight into the topic. In one study, ${ }^{36}$ the general population was included, whereby the overweight participants received an alternative questionnaire assessing the perceived stigmatisation and not their stigmatising attitudes towards obesity. Therefore, only the normal weight sample could be included.

The distribution of women and men was equally considered in the majority of studies, even though more women than men were included. However, two studies posed an exception. The study of Brewis $e t a t^{77}$ and the study of Jiménez-Cruz ${ }^{48}$ investigated only the stigmatising attitudes of female participants.

We also assessed the risk of bias among all studies that fulfilled the inclusion criteria. None of these studies justified the sample size; however, despite a risk of bias regarding the non-responders (ie, no categorisation, description and ratio between the response and non-response rate), the majority of the studies included showed a low risk of bias. Only a few studies were detected to be at moderate risk of bias based on the sampling procedure. ${ }^{36-41}$ The summarised risk of bias assessment of all studies included is provided as an online supplementary table (online supplementary material 1).

\section{Instruments}

The studies included were found to be heterogeneous with regard to the instruments used (tables 3 and 4). Therefore, the study team has decided against a metaanalysis and for a systematic narrative literature review.

\section{Educational attainment and level of income}

Seventeen studies were found that assessed attitudes towards obesity in association with participants' educational attainment and/or level of income. All of these 17 studies reported the participants' educational attainment. ${ }^{10}{ }^{36-51}$ Depending on the origin of the sample and the analogous countries' educational system, categories were formed or years of educational attainment were gathered. From 17 studies, 13 assessed participants' level of income; ${ }^{1036-42} 454648-50$ therefore, income was either assessed by the annual, weekly, household or individual income.

\section{Weight bias in form of stigmatising attitudes}

Studies that examined either participants' stigmatising attitudes or participants' beliefs about the causes of obesity $^{10} 3639404346-4951$ were included. Stigmatising attitudes were thereby measured with instruments such as the Fat Phobia Scale, the Universal Measure of Bias, the Weight Control/Blame of the Antifat Attitude Test, the Attitudes to Obese People (ATOP), the Implicit 


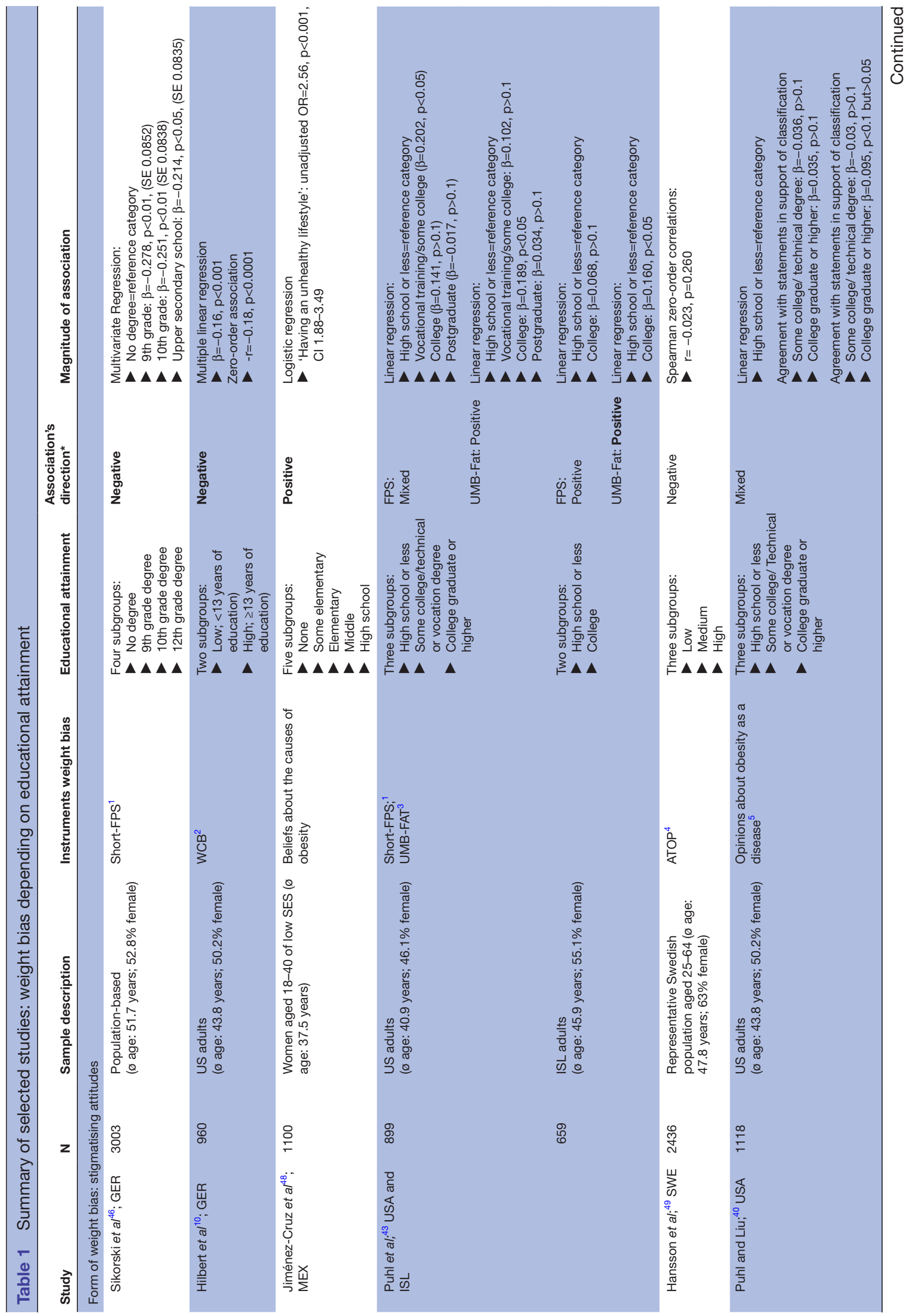



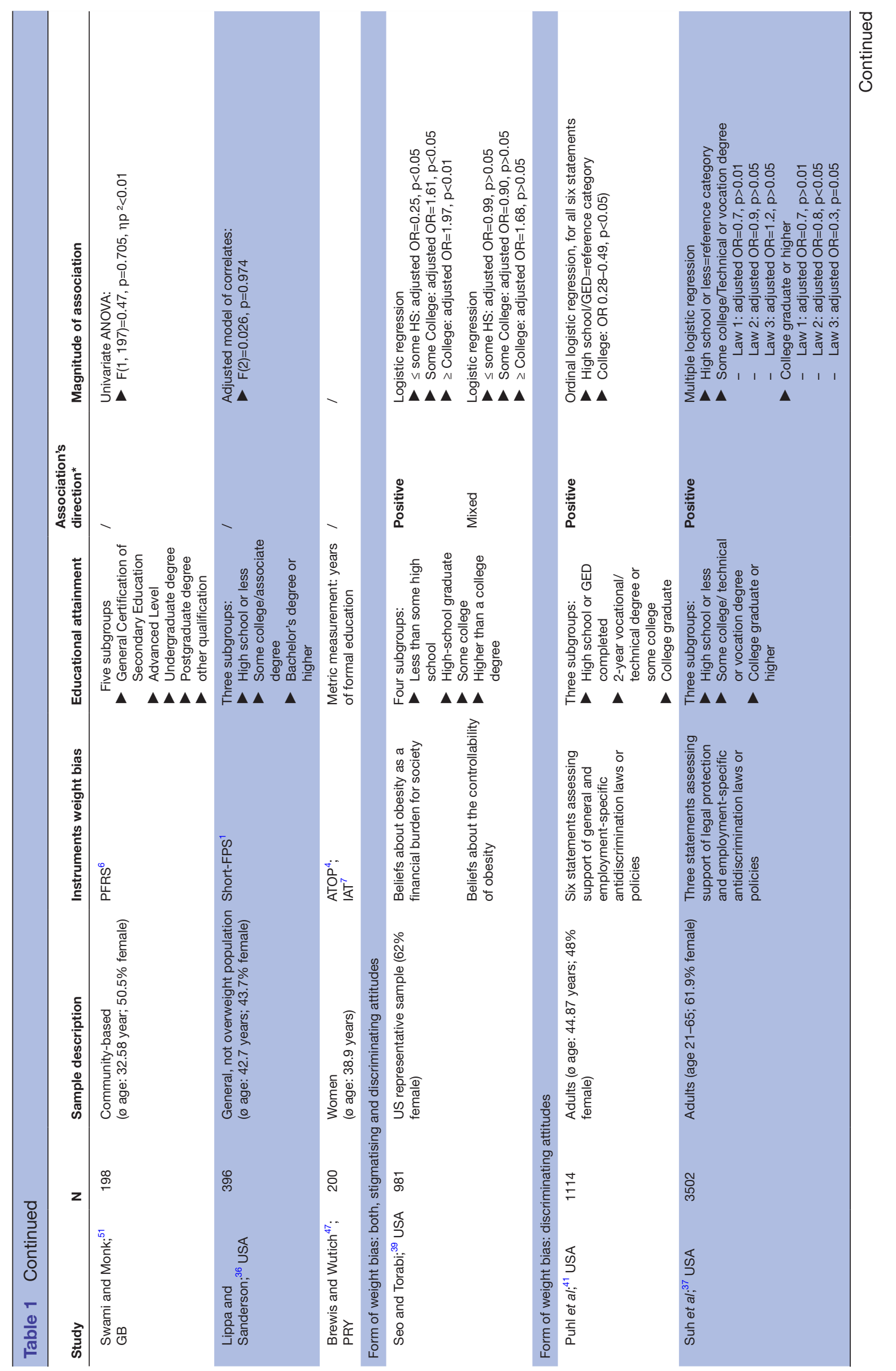


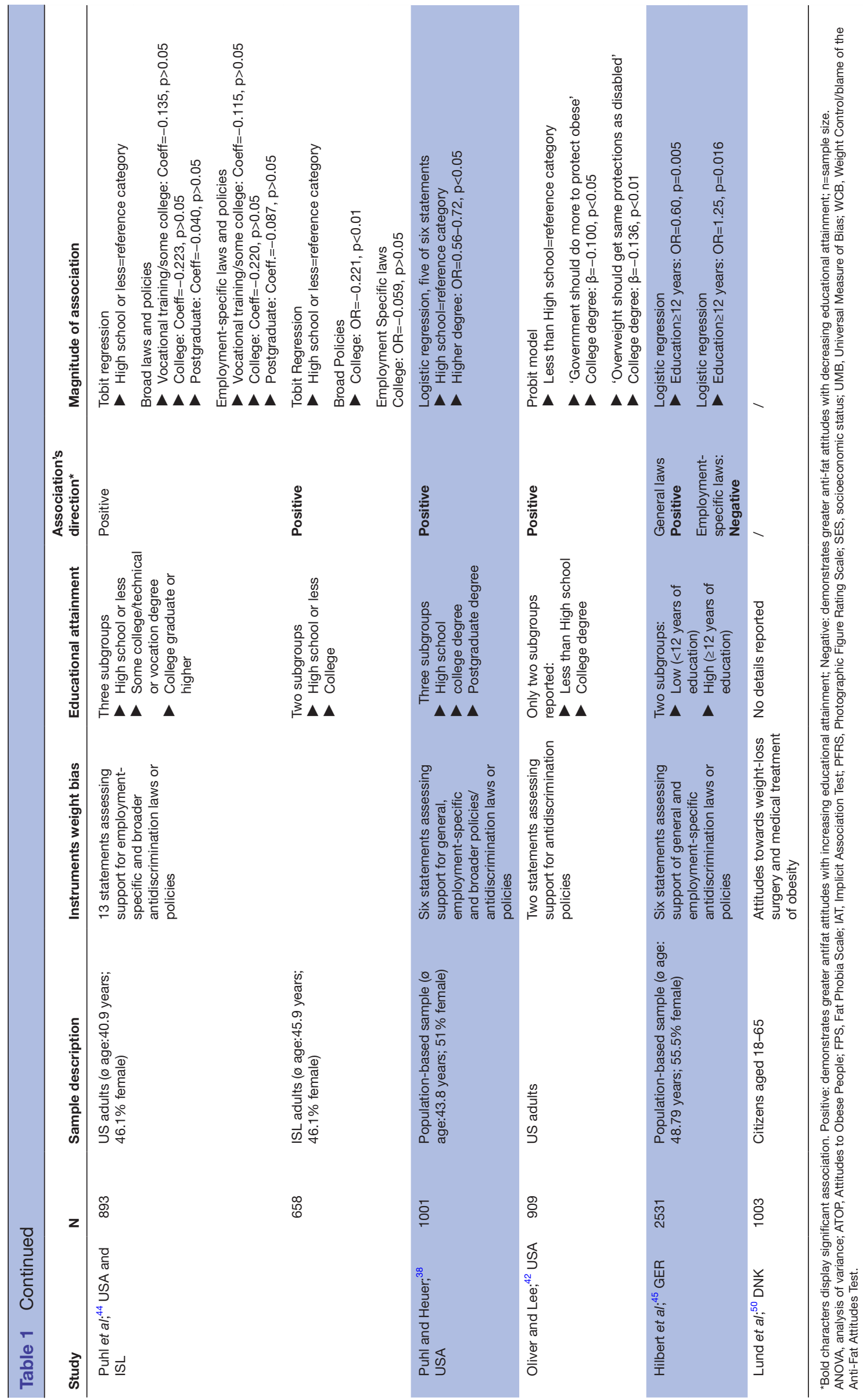


Table 2 Summary of selected studies: weight bias depending on level of income

\begin{tabular}{|c|c|c|c|c|c|c|}
\hline Study & $\mathbf{N}$ & Sample description & $\begin{array}{l}\text { Instruments weight } \\
\text { bias }\end{array}$ & Level of income & $\begin{array}{l}\text { Direction of } \\
\text { correlation* }^{*}\end{array}$ & Magnitude of association \\
\hline \multicolumn{7}{|c|}{ Form of weight bias: stigmatising attitudes } \\
\hline Jiménez-Cruz;; ${ }^{48}$ MEX & 1100 & $\begin{array}{l}\text { Women aged } 18-40 \text { of low } \\
\text { SES (ø age: } 37.5 \text { years) }\end{array}$ & $\begin{array}{l}\text { Beliefs about the } \\
\text { causes of obesity }\end{array}$ & $\begin{array}{l}\text { Weekly income, four } \\
\text { subgroups: } \\
\text { US } \$<1200 \\
\text { US } \$ 1200-2000 \\
\text { US } \$ 2000-4000 \\
\text { US } \$ \geq 4000\end{array}$ & Negative & $\begin{array}{l}\text { Logistic regression } \\
\text { 'Having an unhealthy lifestyle: } \\
\text { unadjusted } O R=1.13, p>0.05, \mathrm{Cl} \\
0.78 \text { to } 1.62\end{array}$ \\
\hline Hilbert; ${ }^{10}$ GER & 960 & $\begin{array}{l}\text { Population-based sample } \\
\text { (ø age: } 45.9 \text { years; } 56.9 \% \\
\text { female) }\end{array}$ & $\mathrm{WCB}^{2}$ & $\begin{array}{l}\text { Monthly income, two } \\
\text { subgroups: } \\
\text { EUR }<2000 \\
\text { EUR } \geq 2000\end{array}$ & Negative & $\begin{array}{l}\text { Zero-order association } \\
r=-0.02, p>0.01\end{array}$ \\
\hline $\begin{array}{l}\text { Hansson and } \\
\text { Rasmussen; }{ }^{49} \text { SWE }\end{array}$ & 2436 & $\begin{array}{l}\text { Representative Swedish } \\
\text { population aged } 25-64 \\
\text { (ø age: } 47.8 \text { years; } 63 \% \\
\text { female) }\end{array}$ & ATOP $^{4}$ & $\begin{array}{l}\text { Annual household income; } \\
\text { no subgroups reported }\end{array}$ & Positive & $\begin{array}{l}\text { Pearson and Spearman zero-order } \\
\text { correlations: } \\
r=0.018, p=0.382\end{array}$ \\
\hline Puhl and Liu; $;^{40}$ USA & 1118 & $\begin{array}{l}\text { US adults } \\
\text { ( } \varnothing \text { age: } 43.8 \text { years; } 50.2 \% \\
\text { female) }\end{array}$ & $\begin{array}{l}\text { Opinions about obesity } \\
\text { as a disease }\end{array}$ & $\begin{array}{l}\text { Annual household income, } \\
\text { five subgroups } \\
\text { US } \$<25000 \\
\text { US } \$ 25000-49999 \\
\text { US } \$ 50000-74999 \\
\text { US } \$ 75000-99999 \\
\text { US } \$>100000\end{array}$ & Mixed & 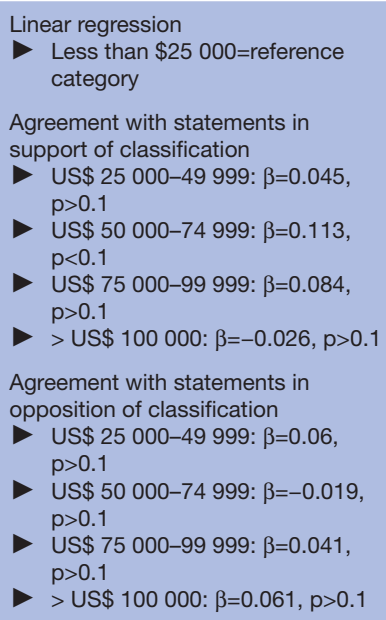 \\
\hline Sikorski; ${ }^{46}$ GER & 3003 & $\begin{array}{l}\text { Population-based } \\
\text { (ø age: } 51.7 \text { years; } 52.8 \% \\
\text { female) }\end{array}$ & Short-FPS ${ }^{1}$ & $\begin{array}{l}\text { Monthly household income, } \\
\text { four subgroups: } \\
\text { EUR<999 } \\
\text { EUR } 1000-1999 \\
\text { EUR 2000-2999 } \\
\text { EUR }>3000\end{array}$ & / & / \\
\hline $\begin{array}{l}\text { Lippa and } \\
\text { Sanderson; }{ }^{36} \text { USA }\end{array}$ & 396 & $\begin{array}{l}\text { General, not overweight } \\
\text { population ( } \varnothing \text { age: } 42.7 \\
\text { years; } 43.7 \% \text { female) }\end{array}$ & Short-FPS ${ }^{1}$ & $\begin{array}{l}\text { Annual household income, } \\
\text { five subgroups: } \\
\text { US } \$<20000 \\
\text { US } \$ 20000-39000 \\
\text { US } \$ 40000-59000 \\
\text { US } \$ 60000-79000 \\
\text { US } \$>80000\end{array}$ & l & $\begin{array}{l}\text { Correlation: } \\
\text { Unadjusted, correlation } \\
\text { coefficient not reported, } \mathrm{p}=0.305\end{array}$ \\
\hline
\end{tabular}

Form of weight bias: both stigmatising and discriminating attitudes

\begin{tabular}{|c|c|c|c|c|c|c|}
\hline \multirow[t]{2}{*}{$\begin{array}{l}\text { Seo and Torabi; } 39 \\
\text { USA }\end{array}$} & \multirow[t]{2}{*}{981} & \multirow[t]{2}{*}{$\begin{array}{l}\text { US representative sample } \\
\text { (62\% female) }\end{array}$} & $\begin{array}{l}\text { Beliefs about obesity } \\
\text { as a financial burden } \\
\text { for society }\end{array}$ & \multirow[t]{2}{*}{$\begin{array}{l}\text { Annual household income, } \\
\text { four subgroups: } \\
\text { US } \$<25000 \\
\text { US } \$ 25000<50000 \\
\text { US } \$ 50000<75000 \\
\text { US } \$ \geq 75000\end{array}$} & Positive & $\begin{array}{l}\text { Logistic regression } \\
\text { US } \$<25000=\text { reference category } \\
\text { US } \$ 25000<50000 \text { : adjusted } \\
\text { OR }=1.02, p>0.05 \\
\text { US } \$ 50000<75000 \text { : adjusted } \\
\text { OR }=1.57, p>0.05 \\
\text { US } \$ \geq 75000 \text { : adjusted } O R=3.18 \\
p<0.001\end{array}$ \\
\hline & & & $\begin{array}{l}\text { Beliefs about the } \\
\text { controllability of } \\
\text { obesity }\end{array}$ & & Negative & $\begin{array}{l}\text { Logistic regression } \\
\text { US } \$<25000=\text { reference category } \\
\text { US } \$ 25000<50000 \text { : adjusted } \\
\text { OR }=0.82, p>0.05 \\
\text { US } \$ 50000<75000 \text { : adjusted } \\
\text { OR }=0.96, p>0.05 \\
\text { US } \$ \geq 75000 \text { : adjusted } O R=0.51 \\
p>0.05\end{array}$ \\
\hline
\end{tabular}




\section{Table 2 Continued}

\begin{tabular}{|c|c|c|c|c|c|c|}
\hline Study & $\mathbf{N}$ & Sample description & $\begin{array}{l}\text { Instruments weight } \\
\text { bias }\end{array}$ & Level of income & $\begin{array}{l}\text { Direction of } \\
\text { correlation* }\end{array}$ & Magnitude of association \\
\hline $\begin{array}{l}\text { Oliver and Lee; } \\
\text { USA }\end{array}$ & 710 & US adults (aged 18-65) & $\begin{array}{l}\text { Two statements } \\
\text { assessing support for } \\
\text { civil protections for the } \\
\text { obese }\end{array}$ & $\begin{array}{l}\text { Annual household income } \\
\text { US } \$<15000 \\
\text { US } \$>100000\end{array}$ & Positive & $\begin{array}{l}\text { Probit Model } \\
\text { 'Government should do more to } \\
\text { protect obese' } \\
\text { US } \$>100.000 \text { : } \beta=-0.098, p<0.01 \\
\text { Overweight should get same } \\
\text { protections as disabled' } \\
\text { US } \$>100.000: \beta=-0.077, p<0.01\end{array}$ \\
\hline Hilbert et al; ${ }^{45}$ GER & 2531 & $\begin{array}{l}\text { Population-based sample } \\
\text { (ø age: } 48.79 \text { years; } 55.5 \% \\
\text { female) }\end{array}$ & $\begin{array}{l}\text { Six statements } \\
\text { assessing support } \\
\text { of general and } \\
\text { employment-specific } \\
\text { antidiscrimination laws } \\
\text { or policies }\end{array}$ & $\begin{array}{l}\text { Monthly income, two } \\
\text { subgroups: } \\
\text { EUR }<2000 \\
\text { EUR } \geq 2000\end{array}$ & $\begin{array}{l}\text { Positive } \\
\text { Positive }\end{array}$ & $\begin{array}{l}\text { Logistic regression } \\
\text { General laws or policies } \\
\text { EUR }<2000=\text { reference category } \\
\text { EUR } \geq 2000 \text { : OR=0.67, } p=0.002 \\
\text { Logistic regression } \\
\text { Employment-specific laws or policies } \\
\text { EUR }<2000=\text { reference category } \\
\text { EUR } \geq 2000 \text { : OR }=0.91, p=0.376\end{array}$ \\
\hline $\begin{array}{l}\text { Puhl and Heuer; } \\
\text { USA }\end{array}$ & 1001 & $\begin{array}{l}\text { Population-based sample } \\
\text { (ø age: } 43.8 \text { years; } 51 \% \\
\text { female) }\end{array}$ & $\begin{array}{l}\text { Six statements } \\
\text { assessing support } \\
\text { for general, } \\
\text { employment-specific } \\
\text { and broader policies/ } \\
\text { antidiscrimination laws } \\
\text { or policies }\end{array}$ & $\begin{array}{l}\text { Annual household income, } \\
\text { five subgroups } \\
\text { US\$15 000-25 } 000 \\
\text { US } \$ 25000-49999 \\
\text { US } \$ 50000-74999 \\
\text { US } \$ 75000-99999 \\
\text { US } \$>100000\end{array}$ & Positive & $\begin{array}{l}\text { Logistic regression, five of six } \\
\text { statements } \\
\text { US } \$ 15000-25,000=\text { reference } \\
\text { category } \\
\text { Adjusted OR=0.52-0.64, } \mathrm{p}<0.05\end{array}$ \\
\hline Puhl et al; $;{ }^{41}$ USA & 1114 & $\begin{array}{l}\text { Adults ( } \varnothing \text { age: } 44.87 \text { years; } \\
48 \% \text { female) }\end{array}$ & $\begin{array}{l}\text { Six statements } \\
\text { assessing support } \\
\text { of general and } \\
\text { employment-specific } \\
\text { antidiscrimination laws } \\
\text { or policies }\end{array}$ & $\begin{array}{l}\text { Annual household income, } \\
\text { five subgroups: } \\
\text { US } \$<25000 \\
\text { US } \$ 25000-49999 \\
\text { US } \$ 50000-74999 \\
\text { US } \$ 75000-99999 \\
\text { US } \$>100000\end{array}$ & Positive & $\begin{array}{l}\text { Ordinal logistic regression } \\
\text { US } \$<25000=\text { reference category } \\
\text { Significant results among women } \\
\text { but not men } \\
\text { 'Obesity should be considered } \\
\text { a disability under the ADA to } \\
\text { protect obese people from weight } \\
\text { discrimination in the workplace' } \\
\text { US } \$ 75000-99 \text { 999: OR }=0.52 \text {, } \\
\text { p }<0.05 \\
\text { 'Congress should pass the WDEA to } \\
\text { protect overweight Americans from } \\
\text { discrimination in the workplace' } \\
\text { US } \$ 75000-99999 \text { : OR=0.49, } \\
\text { p }<0.05\end{array}$ \\
\hline Suh et $a l ;{ }^{37}$ USA & 3502 & $\begin{array}{l}\text { Adults (age } 21-65 ; 61.9 \% \\
\text { female) }\end{array}$ & $\begin{array}{l}\text { Three statements } \\
\text { assessing support of } \\
\text { legal protection and } \\
\text { employment-specific } \\
\text { antidiscrimination laws } \\
\text { or policies }\end{array}$ & $\begin{array}{l}\text { Annual household income, } \\
\text { five subgroups } \\
\text { US\$<25000 } \\
\text { US } \$ 25000-49999 \\
\text { US } \$ 50000-74999 \\
\text { US } \$ 75000-99999 \\
\text { US } \$>100000\end{array}$ & Mixed & 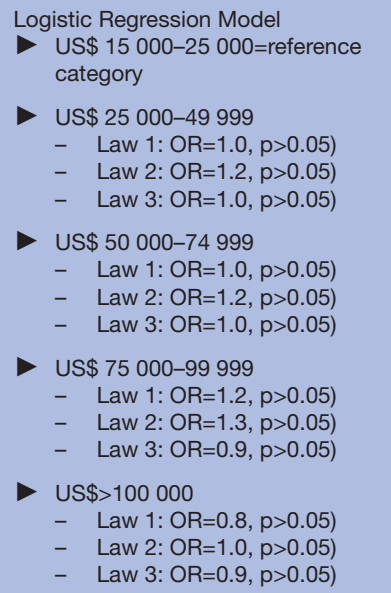 \\
\hline Lund et al $;{ }^{50}$ DNK & 1003 & Citizens (age 18-65) & $\begin{array}{l}\text { Attitudes towards } \\
\text { weight-loss surgery } \\
\text { and medical treatment } \\
\text { of obesity }\end{array}$ & No details reported & / & / \\
\hline
\end{tabular}

*Bold characters display significant association. Positive: demonstrates greater weight bias with increasing level of income; Negative: shows greater weight bias with decreasing level of income; $n=s a m p l e$ size.

ATOP, Attitudes to Obese People; FPS, Fat Phobia Scale; SES, socioeconomic status; WCB, Weight Control/Blame of the Anti-Fat Attitudes Test.; WDEA, Weight Discrimination in Employment Act.

Association Test (IAT) or the Photographic Figure Rating Scale. As described before, beliefs about the causes of obesity in the form of evaluating obesity as a controllable condition-which is supposedly preventable by a greater extent of self-discipline-can consequently be seen as one decisive factor in determining stigmatising attitudes ${ }^{52}$ and was therefore included. The instruments used are presented in table 3 . 
Table 3 Overview of the instruments used to measure stigmatising attitudes

\begin{tabular}{ll}
$\begin{array}{l}\text { Instruments measuring stigmatising } \\
\text { attitudes }\end{array}$ & $\begin{array}{l}\text { Studies that } \\
\text { apply the } \\
\text { instrument }\end{array}$ \\
\hline $\begin{array}{l}\text { Explicit stigma } \\
\text { - FPS }\end{array}$ & 364346 \\
- UMB & 43 \\
- ATOP & 4749 \\
- Opinions about obesity as a disease & 40 \\
- PFRS & 51 \\
Implicit stigma & 47 \\
- IAT & \\
Causal attribution & 10 \\
- WCB & 48 \\
- Potential causes of obesity & 39 \\
- Individuals responsibility ('Obese people & 39 \\
\hline can do something about their weight') & \\
\hline
\end{tabular}

ATOP, Attitudes to Obese People; FPS, Fat Phobia Scale; IAT, Implicit Association Test; PFRS, Photographic Figure Rating Scale; UMB, Universal Measure of Bias; WCB, Weight Control/Blame of the Anti-Fat-Attitudes.

\section{Weight bias in the form of discriminating attitudes}

We found eight studies that investigated participants' discriminating attitudes towards people with obesity. ${ }^{37-394142444550}$ All instruments used to measure discriminating attitudes are listed in table 4. Discrimination was measured for example, by examining policy and law support, but also the ratings on the statement 'Obesity is a major burden to society in terms of healthcare costs' as well as attitudes towards weight-loss surgery and medical treatment. We found some studies ${ }^{373841424445}$ that investigated support for the same or almost identical laws or policies (Law/policy a-i). However, these items were analysed in such heterogeneous way, for example, by merging different items into one, that a meta-analysis could not be conducted.

\section{Findings}

The studies included showed a very heterogeneous picture regarding their results. Eleven out of the 17 studies significantly associated educational attainment (table 5) and/or level of income (table 6) with stigmatising and/or discriminatory attitudes towards people with obesity. ${ }^{10} 37-3941-4648$

\section{Associations between educational attainment and weight- related stigmatisation}

We found 10 studies that reported an association between educational attainment and stigmatising attitudes, whereas only 2 of them ${ }^{43} 48$ showed a positive association between higher educational attainment and weight-related stigmatisation. In addition, the study of Puhl and colleagues ${ }^{434}$ found a significant association in the Icelandic $(\beta=0.160$, $\mathrm{p}<0.05$ ), but not in the American sample. However, two German studies ${ }^{10}{ }^{46}$ showed an inverse correlation. Both of these studies found evidence that higher education is associated with lower stigma ${ }^{46}$ and less belief in individual responsibility ${ }^{10}$ for an obese condition. The remaining studies did not report significant associations.

\section{Associations between educational attainment and weight- related discrimination}

Six studies ${ }^{37-39414244}$ reported increased discriminating attitudes with higher education. The study of Puhl and colleagues found no significant association between weight bias and educational attainment in the US sample, but did find an association in the Icelandic sample $(\beta=-0.221, p<0.01)$. The study of Hilbert and colleagues ${ }^{45}$ revealed inconsistent findings: Higher education is associated with less support for general but more support for employment specific weight-related antidiscrimination laws or policies.

\section{Associations between the level of income and weight-related stigmatisation}

We found no study that reported a significant association between the level of income and weight-related stigmatisation.

\section{Associations between the level of income and weight-related} discrimination

Four American ${ }^{38} 394142$ revealed stronger weight-related discrimination with increasing income. One German study ${ }^{45}$ found less support for general, but not for employment specific policies and laws among more affluent people. Although the study of Suh $e t a l^{37}$ found a significant positive association between level of income and support for two laws and policies (law a: $\chi^{2}=6.06$. $\mathrm{p}=0.01$; law $\left.\mathrm{d}: \chi^{2}=3.81, \mathrm{p}=0.05\right)$, these results could not be validated by logistic regression analysis. Moreover, the assumption that discrimination, in the form of views on the funding for medical or weight-loss surgery, is somehow associated with income was not found. ${ }^{50}$

\section{DISCUSSION}

This systematic literature review aimed to summarise the current state of research on socioeconomic status and its impact on weight-related stigmatisation and discrimination. As it was outlined earlier, the association between socioeconomic factors and weight bias has not been investigated sufficiently. ${ }^{41}$ This review aimed therefore to address this gap. Although many studies were found that investigated various forms of weight bias and assessed socioeconomic data, an association was only reported in 17 studies. The underlying reason why an association was not reported might be a different research focus and also insignificant findings. Overall, 11 out of the 17 studies showed that weight bias is significantly associated with either educational attainment or level of income. In the following the results are discussed separated by education 
Table 4 Overview of the instruments used to measure discriminating attitudes

Instrument measuring discriminating attitudes

Studies that apply the instrument

Attitudes towards weight-loss surgery and medical treatment 50

Beliefs about obesity as a financial burden for society

39

Statements measuring support/rejection of weight-related laws or policies

a. My country/state should include body weight in our civil rights law in order to protect people from 3738414445 discrimination based on their body weight.

b. It should be illegal for an employer to refuse to hire a qualified person because of his or her body 3738414445 weight.

c. It should be illegal for an employer to terminate or fire a qualified employee because of his or her

3738414445 body weight.

d. Fat/overweight persons should be subject to the same legal protections and benefits offered to

373841424445 people with physical disabilities.

e. It should be illegal for an employer to deny a promotion or appropriate compensation to a qualified 37384144 employee because of his or her body weight.

f. Obesity should be considered a disability (under the ADA) so that people will be protected from 38414445 weight discrimination in the workplace.

g. Congress/Government should pass the WDEA to protect overweight Americans from discrimination 384144 in the workplace/employees from discrimination in the workplace based on their body-weight.

h. The government should play a more active role in protecting overweight people from discrimination. 384142

i. It should be illegal for an employer to assign lower wages to a qualified employee because of his or 4445 her body weight.

j. The government should have specific laws in place to protect people from weight discrimination. 44

k. The government should penalise (or fine) those who discriminate against persons because of their 44 weight.

I. Individual companies should have the right to determine whom to hire based on an employee's personal body weight.

m. Employers should be allowed to assign different salaries to employees based on their body weight. 44

n. My country should pass a Healthy Workplace Law to address workplace bullying

44

WDEA, Weight Discrimination in Employment Act.

and income, as well as weight-related stigmatisation and discrimination.

\section{Educational attainment, level of income and stigmatising attitudes}

Overall, 10 studies reported an association between educational attainment and stigmatising attitudes. However, we found no systematic pattern in which way educational attainment and stigmatising attitudes are associated: Two studies ${ }^{43} 48$ supported the hypothesis that stigmatising attitudes are more likely in people with higher educational attainment, whereas two German studies ${ }^{10}{ }^{46}$ contradict this. Moreover, six studies 363940474951 did not show any significant association or a clear direction of the assumed association. In light of divergent results of studies that report a significant association between socioeconomic variables and stigmatising attitudes, the findings must be discussed with regard to their cultural context: American, Mexican and Icelandic studies were found to support the working hypothesis, whereas two German studies ${ }^{10} 46$ revealed findings to the contrary.
These differences might be explained when considering cultural distinctions. In cultures, in which individual responsibility is considered as one of the leading causes of self-fulfilment, health and wealth, obesity might be perceived as a self-inflicted condition. Highly educated people might attempt to keep people down to maintain their high(er) social status. In contrast, in cultures in which individuals' situations are principally considered as a result of various circumstances, obesity might consequently not only be seen as self-inflicted. In these cultures, especially highly educated people might be aware of social barriers as determinants for self-fulfilment, wealth and health, that is, body weight. In conclusion, the direction of the relationship between weight bias and socioeconomic status might depend on divergent sociocultural perspectives. Hence, future research should consider expansion and reorientation of stigma's theoretical framework by focusing on the meso and macro sociocultural structures, as Bonnington and Rose ${ }^{53}$ suggest.

Overall, we found eight studies that investigated (or rather reported) the association between level of income 


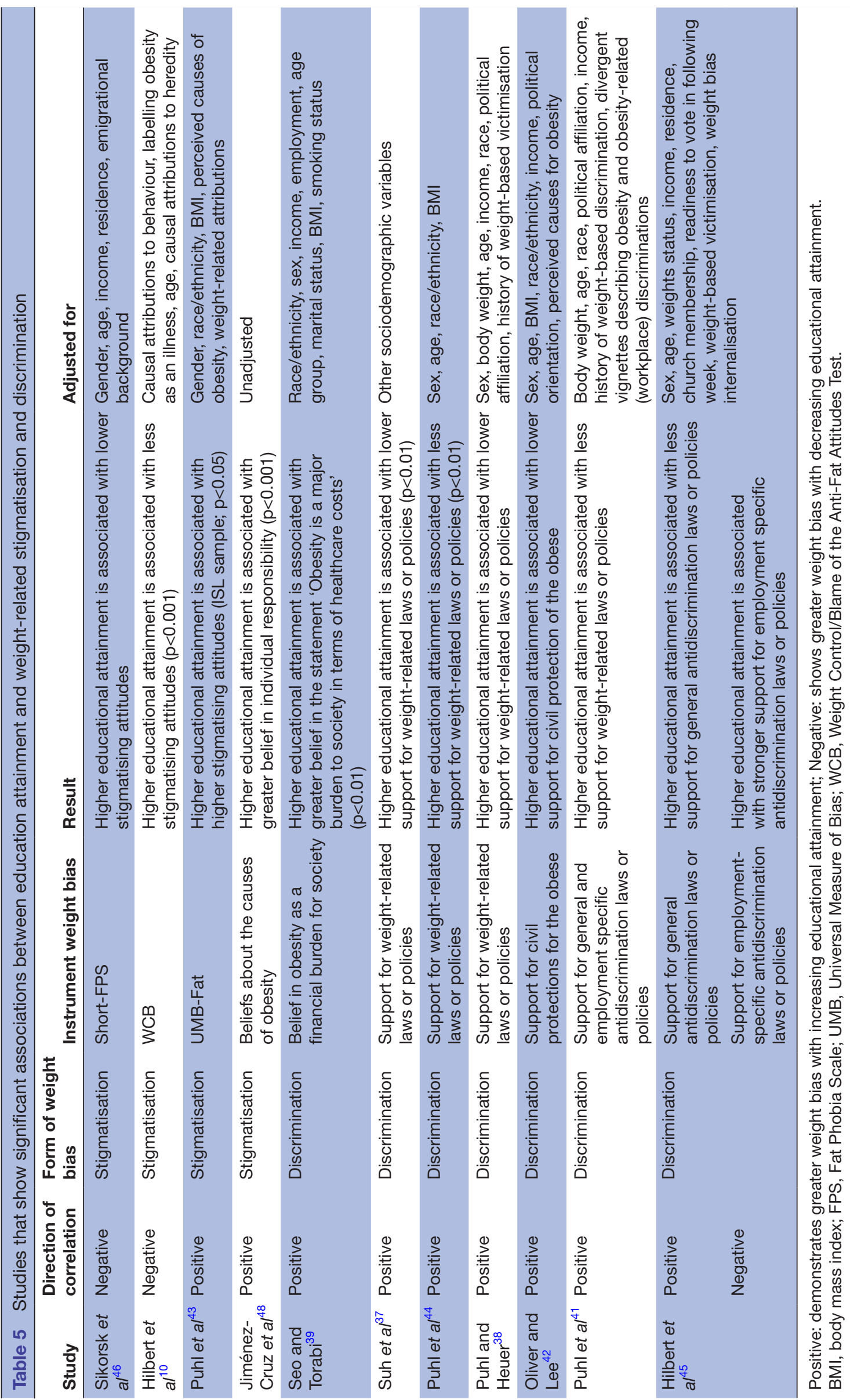




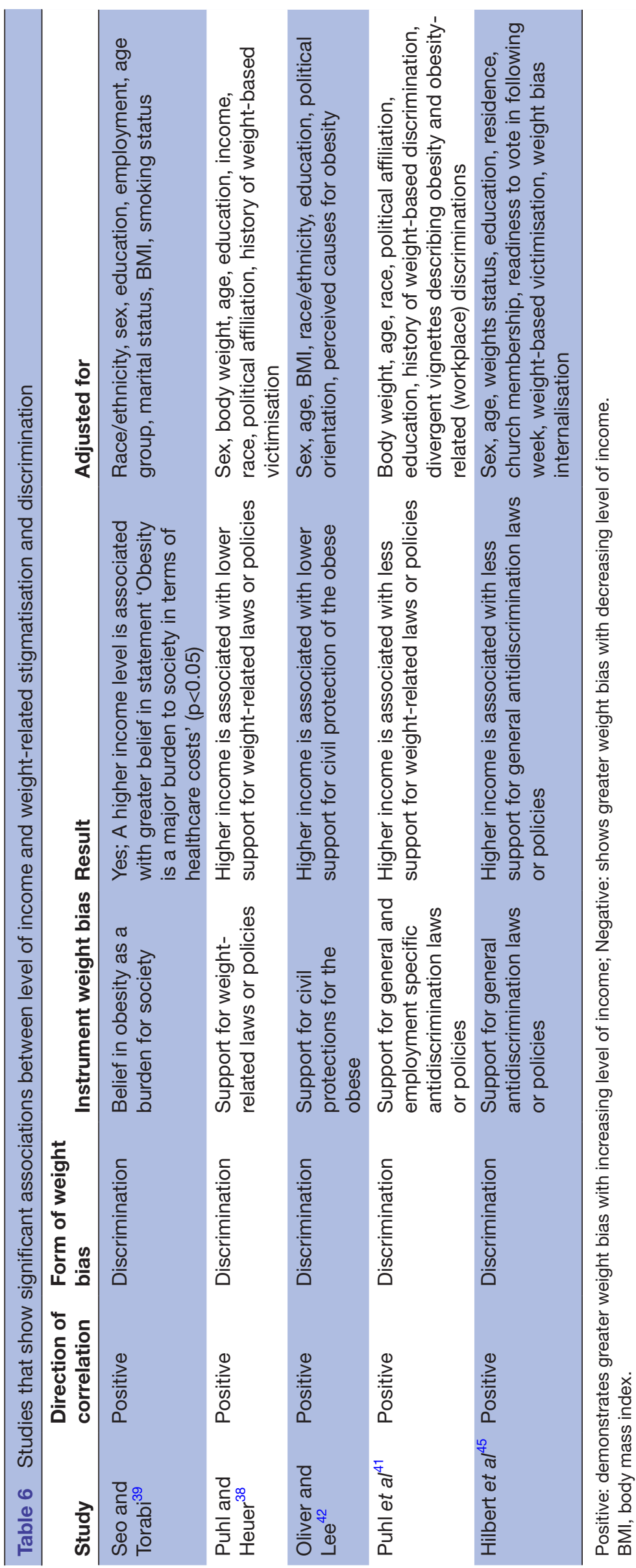


and stigmatising attitudes. None of these studies showed a significant relationship. However, the direction of the (insignificant) associations did not show any pattern. We found three studies reporting an (insignificant) positive association, ${ }^{10} 3948$ and one study each reporting an (insignificant) positive ${ }^{49}$ or mixed associations. ${ }^{40}$

\section{Educational attainment, level of income and discriminating attitudes}

Of the 17 studies included, 8 studies were found that reported an association between educational attainment and discriminating attitudes. Five of these studies reported a positive relationship, that is, stronger discriminating attitudes (in the form of law and policy support) with increasing education. Another study ${ }^{44}$ that applied the same instruments for an American and an Icelandic sample found only indications for our assumption (ie, higher education is associated with stronger discriminating attitudes) in the Icelandic, but not in the American sample. This study ${ }^{44}$ was also replicated by Hilbert et $a l,{ }^{45}$ who report heterogeneous findings as they found less support for general antidiscrimination laws with increasing level of education, but stronger support for employment specific laws and policies among the higher educated German sample. It should, therefore, be discussed whether general and employment-specific antidiscrimination policies and laws can be viewed as similar outcomes or if they display different dimensions of discrimination. Moreover, views on who should pay for medical treatment or weight-loss surgery did not reveal significant associations. ${ }^{50}$ Only one study ${ }^{50}$ did not find a significant association between educational attainment and discriminating attitudes, nor did it report the direction of the insignificant association.

With regard to the association between level of income and discriminating attitudes, we found overall seven studies in which an association was reported. Five studies $^{38} 39414245$ reported positive relationships, that is, stronger discriminating attitudes with an increasing level of income. Suh $e t a l^{\beta 7}$ found a significant association of stronger support for weight-related laws with decreasing income until they controlled for other sociodemographic variables, such as educational attainment. They reported mixed (insignificant) results concerning the direction of the assumed association. A possible explanation for these insignificant results after controlling for education might be that income can be seen as a proxy variable for education, in the way that the level of income depends on educational attainment. Again, Lund and colleagues ${ }^{50}$ who asked Danish citizen by whom medical treatment and weight-loss surgery should be funded, found no significant association, nor did they report a direction of the association.

These findings support our assumption that higher socioeconomic status is associated with stronger discriminating attitudes. However, one German study ${ }^{45}$ reported contradicting results that might be ascribed at a macrolevel to Bourdieu's theory about how cultural frameworks determine how specific values and characteristics are perceived. Governmental structures might enforce stigmatising and discriminating attitudes as an instrument to 'nudge people into desired patterns of behaviour'. ${ }^{29}$ It can be assumed that cultural frameworks shape governmental systems and are strengthened at the same time through them, especially through the national health and welfare systems. Tyler and Slater, ${ }^{29}$ for example, outline the political and social function of stigma as a form of power. They discuss macrolevel structures, particularly those used actively and passively by governments, as determinants shaping stigmatising and discriminating attitudes, a level of understanding often left out in social psychology. As explained above, it might be possible that in countries in which obesity is merely perceived as self-inflicted, discriminating attitudes might be stronger-Hence, stigma is an instrument used by individuals to enforce personal interests and one put in place (intended or not) by governments.

The different and to some extent inconclusive results might be caused by diverging study designs, sample sizes and instruments assessing weight-related stigmatisation and discrimination, educational attainment and level of income: Studies that did not show a significant association between weight bias and either educational attainment or level of income excluded the overweight portion of the sample ${ }^{36}$ or were characterised by a small sample (ranging from $\mathrm{n}=198$ to $\mathrm{n}=396$ ) size.$^{364751}$ Furthermore, the association between weight bias with either educational attainment or level of income was not seen in instruments such as the ATOP scale, ${ }^{47} 49$ the IAT $^{47}$ agreement ratings as to whether obesity can be classified as a disease $^{40}$ and measurement of attitudes towards weightloss surgery and medical treatment. ${ }^{50}$

However, there are findings diminishing this line of argument: The study of Hilbert $e t a t^{45}$ found less support for general, but stronger support for employment specific laws with increasing socioeconomic status. In addition, the German population was found to be less supportive of laws and policies that would impede to refuse to hire, assign lower wages and to fire qualified persons because of their body weight, compared with an American and Icelandic sample. ${ }^{44}$ Moreover, the German population was less supportive of including body weight in the civil rights of law compared with the American, but not the Icelandic sample.

A final point of discussion might be whether the prevalence of obesity has an impact on the magnitude of weight bias. When comparing the prevalence and the stigmatisation of obesity between the USA and Germany, for example, the following can be stated: In both countries, the prevalence of obesity increased over time (1995, USA 21.9\%; GER 14.5\%; 2005 USA $29 \%$; GER $18 \%) .{ }^{54}$ However, the prevalence of obesity itself increased, along with the (perceived) stigmatisation towards people with obesity in the USA and in Germany. $^{781055}$ 


\section{Limitations}

Just as any overview must contend with heterogeneous samples and instruments, this systematic review has likewise attempted to cope with varying data. The studies reviewed differed with respect to the instruments used to assess education and income. In particular, the measurement of educational attainment was strongly influenced by the different organisation and structure of the varied local educational systems. In addition, the instruments to assess weight bias were also heterogeneous, particularly those used to measure stigmatising attitudes. Some studies used validated scales, whereas other studies used single items only. Thus, the manner of gathering data and classifying categories can be described as heterogeneous itself-and therefore caused the study team to decide against a meta-analysis. However, studies that did use the same instrument, such as items weighing support for specific laws and policies differed with regard to how they were analysed (as single items or as an item battery). Therefore, the authors had to decide again against a metaanalysis and applied a vote-counting approach despite its shortcomings.

Moreover, the study aimed to investigate socioeconomic determinants of weight bias in the general population, as discussed in the inclusion and exclusion section. Therefore, we excluded, among other things, studies that focused on overweight and/or obese samples only. We assumed that people try to differentiate themselves from lower status groups, which might be characterised by varying body sizes, that is, excess weight or obesity. However, overweight and obese samples were included as part of the general population in some studies. Also, these studies did not differentiate their results by participants' body sizes. We also excluded studies based on homogenous samples, such as healthcare professionals and students. We considered these studies as inadequate since there would have been no possibility to compare and thus interpret these results with regard to the research question. Moreover, stigmatising attitudes among some professions, such as dietitians and nutritionists, were already investigated systematically.

In the general population, we assume that people try to differentiate themselves by socioeconomic status and by other status markers as well, such as excess weight. Although we attempted to explain the heterogeneous and inconclusive results by appealing to governmental and cultural differences, there was insufficient (and also inconclusive) evidence to conclude the role of cultural and governmental structures on weight bias.

Since the study team has only sufficient language skills in English and German, the current research includes only papers written in English or German

\section{CONCLUSION}

The literature review aimed to investigate to what extent weight bias can be traced back to socioeconomic variables, such as educational attainment and level of income.
We assumed that a higher level of education or income is associated with greater stigmatisation and discrimination. Therefore, the current study situation was analysed systematically. Although data of education and income are always collected as mandatory sociodemographic information, research is lacking when it comes to examining their impact on weight bias. Since this question has not yet been answered sufficiently, this review was supposed to address this gap in research and aimed to contribute to closing this gap.

Our working hypothesis that weight bias increases with higher educational attainment or level of income could not be verified. Particularly, we found eight studies that supported our hypothesis, two German studies indicating the reverse conclusion, one German study reported heterogonous findings and seven studies that did not show a significant association at all.

The key to identifying effective interventions to battle stigmatisation, discrimination and consequences for those affected might lie in exposing the characteristics of stigmatising groups and their motivations. Therefore, future research should pay more attention to the link between weight bias and socioeconomic factors and cultural or rather governmental structures. Moreover, meta-analysis should be considered as an important direction for future research.

Acknowledgements We acknowledge support from the German Research Foundation (DFG) and University Leipzig within the program of Open Access Publishing.

Contributors MB, CL-S and SGR-H outlined and specified the research question. $M B$ and CL-S conducted the systematic search of the literature. Furthermore, MB, CL-S and TF discussed papers in detail in case of disagreement and uncertainty over the eligibility of abstracts. MB wrote the first draw of the manuscript. TF, SGR-H and CL-S revised it critically for valuable intellectual content. All authors contributed to and have approved the final manuscript.

Funding This study was supported by the Federal Ministry of Education and Research (BMBF), Germany, FKZ: 01E01501.

Disclaimer The funding source had no involvement in study design, collection, analysis and interpretation of data.

Competing interests None declared.

Patient consent for publication Not required.

Provenance and peer review Not commissioned; externally peer reviewed. Data availability statement No data are available.

Open access This is an open access article distributed in accordance with the Creative Commons Attribution Non Commercial (CC BY-NC 4.0) license, which permits others to distribute, remix, adapt, build upon this work non-commercially, and license their derivative works on different terms, provided the original work is properly cited, appropriate credit is given, any changes made indicated, and the use is non-commercial. See: http://creativecommons.org/licenses/by-nc/4.0/.

ORCID iD

Marie Bernard http://orcid.org/0000-0003-4208-4057

\section{REFERENCES}

1 World Health Organization. Obesity and overweight, 2018. Available: http://www.who.int/en/news-room/fact-sheets/detail/obesity-andoverweight [Accessed 27 Aug 2018].

2 Mensink GBM, Schienkiewitz A, Haftenberger M, Scheidt-Nave C, et al. [Overweight and obesity in Germany: results of the German Health Interview and Examination Survey for Adults (DEGS1)]. 
Bundesgesundheitsblatt Gesundheitsforschung Gesundheitsschutz 2013:56:786-94.

3 Flegal KM, Kruszon-Moran D, Carroll MD, et al. Trends in obesity among adults in the United States, 2005 to 2014. JAMA 2016;315:2284-91.

4 Pi-Sunyer X. The medical risks of obesity. Postgrad Med 2009;121:21-33.

5 Jung FUCE, Luck-Sikorski C, Wiemers N, et al. Dietitians and Nutritionists: stigma in the context of obesity. A systematic review. PLoS One 2015;10:e0140276.

6 Puhl RM, Heuer CA. The stigma of obesity: a review and update. Obesity (Silver Spring) 2009;17:941-64.

7 Andreyeva T, Puhl RM, Brownell KD. Changes in perceived weight discrimination among Americans, 1995-1996 through 2004-2006. Obesity (Silver Spring) 2008;16:1129-34.

8 Spahlholz J, Baer N, König H-H, et al. Obesity and discrimination - a systematic review and meta-analysis of observational studies. Obes Rev 2016;17:43-55.

9 Puhl RM, Andreyeva T, Brownell KD. Perceptions of weight discrimination: prevalence and comparison to race and gender discrimination in America. Int $J$ Obes (Lond) 2008;32:992-1000.

10 Hilbert A, Rief W, Braehler E. Stigmatizing attitudes toward obesity in a representative population-based sample. Obesity (Silver Spring) 2008;16:1529-34.

11 Rand CS, Wright BA. Continuity and change in the evaluation of ideal and acceptable body sizes across a wide age span. Int $J$ Eat Disord 2000;28:90-100.

12 Schwartz MB, Chambliss HO, Brownell KD, et al. Weight bias among health professionals specializing in obesity. Obes Res 2003:11:1033-9.

13 Crandall CS. Prejudice against fat people: ideology and self-interest. J Pers Soc Psychol 1994;66:882-94.

14 Puhl RM, Schwartz MB, Brownell KD. Impact of perceived consensus on stereotypes about obese people: a new approach for reducing bias. Health Psychol 2005;24:517-25

15 Latner JD, Stunkard AJ, Wilson GT. Stigmatized students: age, sex, and ethnicity effects in the stigmatization of obesity. Obes Res 2005;13:1226-31.

16 Perez-Lopez MS, Lewis RJ, Cash TF. The relationship of Antifat attitudes to other Prejudicial and gender-related Attitudes1. J Appl Soc Psychol 2001;31:683-97.

17 Link BG, Phelan J, power S. Stigma power. Soc Sci Med 2014:103:24-32.

18 McLaren L. Socioeconomic status and obesity. Epidemiol Rev 2007;29:29-48.

19 Brewis AA, McGarvey ST, Jones J, et al. Perceptions of body size in Pacific Islanders. Int J Obes Relat Metab Disord 1998;22:185-9.

20 Brewis AA, Wutich A, Falletta-Cowden A, et al. Body norms and fat stigma in global perspective. Curr Anthropol 2011;52:269-76.

21 Flint SW, Čadek M, Codreanu SC, et al. Obesity Discrimination in the Recruitment Process: 'You're Not Hired!'. Front Psychol 2016;7:647.

22 Agerström J, Rooth D-O. The role of automatic obesity stereotypes in real hiring discrimination. J Appl Psychol 2011;96:790-805.

23 Puhl R, Brownell KD, Bias BKD. Bias, discrimination, and obesity. Obes Res 2001;9:788-805.

24 Flaskerud JH, DeLilly CR, Flaskerud JH. Social determinants of health status. Issues Ment Health Nurs 2012;33:494-7.

25 Bourdieu P. Distinction: a social critique of the judgement of taste. 1984th edn. Cambridge, Mass: Harvard University Press, 2000.

26 Cockerham WC. Health lifestyle theory and the convergence of agency and structure. J Health Soc Behav 2005;46:51-67.

27 Bourdieu P. What makes a social class? on the theoretical and practical existence of groups. Berkeley J Sociol 1987;32:1-17.

28 Phelan JC, Link BG, Dovidio JF. Stigma and prejudice: one animal or two? Soc Sci Med 2008;67:358-67.

29 Tyler I, Slater T. Rethinking the sociology of stigma. Sociol Rev 2018:66:721-43.

30 Moher D, Liberati A, Tetzlaff J, et al. Preferred reporting items for systematic reviews and meta-analyses: the PRISMA statement. BMJ 2009;339:b2535.
31 Howard C. Subject \& course guides: evidence based medicine: PICO. Available: https://researchguides.uic.edu/c.php?g=252338\&p= 3954402 [Accessed 14 Aug 2019].

32 Puhl RM, Latner JD, Stigma LJD. Stigma, obesity, and the health of the nation's children. Psychol Bull 2007;133:557-80.

33 Woolford SJ, Clark SJ, Butchart A, et al. To pay or not to pay: public perception regarding insurance coverage of obesity treatment. Obesity (Silver Spring) 2013;21:E709-14.

34 Biener A, Cawley J, Meyerhoefer C. The high and rising costs of obesity to the US health care system. J Gen Intern Med 2017;32:6-8.

35 Downes MJ, Brennan ML, Williams HC, et al. Development of a critical appraisal tool to assess the quality of cross-sectional studies (axis). BMJ Open 2016;6:e011458.

36 Lippa NC, Sanderson SC. Impact of information about obesity genomics on the stigmatization of overweight individuals: an experimental study. Obesity (Silver Spring) 2012;20:2367-76.

37 Suh Y, Puhl R, Liu S, et al. Support for laws to prohibit weight discrimination in the United States: public attitudes from 2011 to 2013. Obesity (Silver Spring) 2014;22:1872-9.

38 Puhl RM, Heuer CA. Public opinion about laws to prohibit weight discrimination in the United States. Obesity (Silver Spring) 2011;19:74-82

39 Seo D-C, Torabi MR. Racial/ethnic differences in body mass index, morbidity and attitudes toward obesity among U.S. adults. $J$ Natl Med Assoc 2006;98:1300-8.

40 Puhl RM, Liu S. A national survey of public views about the classification of obesity as a disease. Obesity (Silver Spring) 2015;23:1288-95.

41 Puhl RM, Heuer C, Sarda V. Framing messages about weight discrimination: impact on public support for legislation. Int $J$ Obes (Lond) 2011;35:863-72.

42 Oliver JE, Lee T. Public opinion and the politics of obesity in America. $J$ Health Polit Policy Law 2005;30:923-54.

43 Puhl RM, Latner JD, O'Brien $\mathrm{K}$, et al. A multinational examination of weight bias: predictors of anti-fat attitudes across four countries. Int J Obes(Lond) 2015;39:1166-73.

44 Puhl RM, Latner JD, O'Brien KS, et al. Potential policies and laws to Prohibit weight discrimination: public views from 4 countries. Milbank Q 2015;93:691-731.

45 Hilbert A, Hübner C, Schmutzer G, et al. Public support for weight-related Antidiscrimination laws and policies. Obes Facts 2017:10:101-11.

46 Sikorski C, Luppa M, Brähler E, et al. Obese children, adults and senior citizens in the eyes of the general public: results of a representative study on stigma and causation of obesity. PLoS One 2012; 7:e46924

47 Brewis AA, Wutich A. Explicit versus implicit fat-stigma. Am J Hum Biol 2012;24:332-8.

48 Jiménez-Cruz A, de Escobar-Aznar YM, Castillo-Ruiz O, et al. Beliefs about causes and consequences of obesity among women in two Mexican cities. J Health Popul Nutr 2012;30:311-6.

49 Hansson LM, Rasmussen F. Attitudes towards obesity in the Swedish general population: the role of one's own body size, weight satisfaction, and controllability beliefs about obesity. Body Image 2014;11:43-50.

50 Lund TB, Nielsen MEJ, Sandøe P. In a class of their own: the Danish public considers obesity less deserving of treatment compared with smoking-related diseases. Eur J Clin Nutr 2015;69:514-8.

51 Swami V, Monk R. Weight bias against women in a university acceptance scenario. J Gen Psychol 2013;140:45-56.

52 Gorman MJ, Butsch WS, Reilly-Harrington NA. Stigma In Persons with Obesity. In: Parekh R, Childs EW, eds. Stigma and prejudice: Touchstones in understanding diversity in healthcare. Cham: Springer International Publishing, 2016: 23-40.

53 Bonnington O, Rose D. Exploring stigmatisation among people diagnosed with either bipolar disorder or borderline personality disorder: a critical realist analysis. Soc Sci Med 2014;123:7-17.

54 World Health Organization. Overweight and obesity. Available: https://www.who.int/gho/ncd/risk_factors/overweight_obesity/ obesity_adults/en/ [Accessed 14 Aug 2019].

55 Herpertz S, Zwaan M, Zipfel S. Handbuch Essstörungen und Adipositas. Berlin, Heidelberg: Springer Berlin Heidelberg, 2015. 